\title{
THE EFFECT OF EMOTIONAL INTELLIGENCE ON JOB SATISFACTION MEDIATED BY ORGANISATIONAL JUSTICE AND JOB INSECURITY: STUDY IN ACEH PROVINCE GOVERNMENT SECRETARIAT
}

\author{
*Isfan Zeldy, Nasir and Teuku Roli Ilhamsyah Putra \\ Department of Management, UniversitasSyiah Kuala, Indonesia \\ http://doi.org/10.35409/IJBMER.2020.3186
}

\begin{abstract}
This research examines the effect of emotional intelligence on job satisfaction mediated by organizational justice and job insecurity in Aceh Province Government Secretariat. The population were leaders and employees, amounting to 595 people. The sample was determined using proportionate stratified random sampling technique, as a systematic random sample selection of subjects which is done by dividing the population as many as $\mathrm{n}$ parts and taking samples in each part starting from the first part randomly. The Slovin formula provided the number of samples as much as 161 respondents. The model was tested using Structural Equation Modeling (SEM). The finding shows that emotional intelligence affects employee organizational justice, emotional intelligence affects job insecurity, emotional intelligence affects employee job satisfaction, organizational justice affects employee job satisfaction, job insecurity affects employee job satisfaction, organizational justice mediates the influence of emotional intelligence on job satisfaction, job insecurity mediates the influence of emotional intelligence on job satisfaction. These findings contribute academically, especially in the renewal of the theory of causality and can be a reference for practical leaders, especially those in the Aceh Province Government Secretariat. The novelty of the results of this study lies in the combination of previous causality research models, using a new object. The interesting issue in the research model resides in the use of the organizational justice and job insecurity as mediators. The limitation of the study resides in the number of variables studied and the scope of the study
\end{abstract}

Keyword: Emotional Intelligence, Job Satisfaction, Justice, Job Insecurity.

\section{INTRODUCTION}

The Aceh Regional Secretariat (SETDA) is a government organization, in accordance with the Aceh Qanun number 14 of 2012 concerning amendments to the Aceh Qanun number 4 of 2007 concerning the organizational structure and work administration of the SETDA which organizes the Aceh administration consisting of the Governor, deputy governor, as command of Regional/Province Secretary (SEKDA). SEKDA's role is not only as a supervisor for expert staff but also as a command of the Government Assistant called assistant 1, Aceh Development and Economic Specialist Assistant called assistant 2, and General Administration Assistant also called Assistant 3. Assistant 1, Assistant 2, and Assistant 3 also have elements the assistant is 


\section{International Journal of Business Management and Economic Review}

Vol. 3, No. 04; 2020

ISSN: 2581-4664

called a bureau, consisting of eight bureaus, namely the Governance Bureau, the Legal Bureau, the Privileges and Welfare Bureau, the Development Administration Bureau, the Economic Bureau, the Goods and Services Procurement Bureau, the Organization Bureau, the General Bureau, and the Public Relations and Protocol Bureau.

The existence of a regional secretary who is a public organization or institution to serve the interests of the community can respond to the process of progress and development of the community by determining an acceptable service vision. As a public institution, the Government of Aceh has the task and also the obligation to assist the Governor in formulating the draft policy and coordinating it with the regional offices, regional technical institutions, and regional institutions. As a key organizational instrument in the Government of Aceh, the regional secretariat is expected to be more responsive in dealing with various demands for change, in other words not only working by following a set of rules or instructions, or by order of its superiors, but also as an apparatus demanded to be creative and innovative in translating and implementing rules according to the needs that are aspirated by the community(Muttaqin, Djumadi, \& Noor, 2013).

The smooth implementation of local government and the implementation of regional and national development is very dependent on the perfection, ability, innovation, motivation and willingness of the apparatus to carry out and protect the development policies and services it carries out as outlined in the main duties and functions of each state apparatus. In this connection and in the context of efforts to achieve organizational goals, the performance of the state civil service (ASN) within the Aceh Regional Secretariat is required to be able to display its performance optimally to provide more satisfying services to the community. That is because ASN has a very important role to carry out development in order to create a civil society. If the ASN found in an agency is bad, then the agency's goals cannot be achieved as planned.

High performance is an important thing that must be achieved by every agency, because performance is a reflection of the agency's ability to manage and allocate its resources. Human resources (HR) are required to provide a competitive advantage in an effort to support the sustainability of optimal organizational performance. Its competitive advantage can be seen from the aspects of the knowledge, skills, and attitudes and work behavior of its employees that are directed and aligned to the achievements of their organizational goals. The rapid development of technology and information, as well as science today makes globalization must be taken into account as a determinant component of strategic activities, because globalization has a major influence on changes in systems and values in society, community organizations, and also government organizations including the Aceh Province Government Secretariat.

In an organization, of course, it really needs potential human resources both in the position of leader and employee. The pattern of assignment and supervision is also a determining factor in achieving the objectives of the organization. The quality of employee HR is one of the factors that play an important role in increasing the productivity of organizational performance. For this reason, it takes HR who has high competence because competence or expertise will be able to support an organization's performance improvement. Employees include the main assets that have a strategic role in the organization, namely as a manager or executor that starts from the planning, implementation, control and monitoring of all activities of an organization in achieving organizational performance in accordance with the direction of vision, mission and also the goals of the organization itself. So far, most of which occur in government agencies, employees who 


\section{International Journal of Business Management and Economic Review}

Vol. 3, No. 04; 2020

ISSN: 2581-4664

have adequate competence are still very few in number. This is evidenced from the low performance of employees. The difficulty of measuring a real employee performance in the environment of government agencies is also a problem.

The success of an organization in this case the Aceh Regional Secretariat is greatly influenced by employee job satisfaction. Employees who are dissatisfied with the agency will tend to give mediocre performance and even lower than expected. Job satisfaction becomes an ongoing topic and is often discussed among experts in the field of corporate psychology and management. Dissatisfaction and low levels of employee satisfaction can lead to disruptions, obstacles and also the disruption of work processes within the organization. Factors that can foster job satisfaction include an attitude of mutual respect between fellow colleagues and an attitude that is shown by the leadership to every employee, and the ability of employees to overcome boredom at work. In addition to these factors, organizational justice and job insecurity can also affect job satisfaction. (Colquitt, 2001)states that organizational justice has three dimensions, namely distributive justice, procedural justice, interactional justice.

Unsafe feelings will certainly have an impact on employee attitudes, even when they manage the emotional intelligence they feel to job satisfaction is high so that the perception of insecurity in work has an impact on psychological aspects. The factor of job insecurity is probably due to the low emotional intelligence of employees so employees feel worried if they have to leave their work prematurely, there is also a risk that they will have to leave their current job, and they feel uneasy about losing their jobs in the near future. Individuals need to have intelligence in managing their emotions because emotional conditions can impact on thoughts, words, and behavior, including in work. Individuals who can manage their emotional intelligence will be able to know the condition of their emotions and can also express their emotions in an appropriate manner so that their emotions can be controlled and provide many uses in everyday life. Many people are smart in academic terms but lack an emotional intelligence, it can fail in achieving success in the place of work.

Thus, all employees must have a sense of satisfaction at work and they must know and be able to apply ways to recognize emotions, manage emotions, motivate yourself, recognize the emotions of others (empathy), and cooperate with others, which is all are a reflection of their emotional intelligence to be maintained in their position or work. By having good emotional intelligence, a person can act decisively and can make decisions that tend to be positive and good even in a depressed state. They will keep thinking clearly and keep their jobs even though they know their results as employees, act according to ethics, stick to principles and have a drive for achievement. As time goes by they also want recognition as employees due to factors of their emotions and their satisfaction at work.

Based on the background discussed above, the researcher found several problems so that the researcher formulated the research related to the influence of emotional intelligence on job satisfaction mediated by organizational justice and job insecurity at the Aceh Province Government Secretariat institution.

\section{LITERATURE STUDY Job Satisfaction}

Job satisfaction is a happy emotional state or a positive emotion that comes from evaluating a person's work or work experience. Job satisfaction is also the result of employees' perceptions 


\section{International Journal of Business Management and Economic Review}

Vol. 3, No. 04; 2020

ISSN: 2581-4664

about how well their work can provide what is considered important(Luthans, 2006). (Greenberg \& Baron, 2007)defined job satisfaction as a positive attitude or negative attitude of each individual towards his job. Meanwhile according to(Robbins \& Judge, 2014)job satisfaction is a positive feeling about a job based on an evaluation of job characteristics. (Rivai \& Mulyadi, 2003)explained that the so-called job satisfaction is the assessment of workers about how far the job as a whole can satisfy their needs. (Lévy-Garboua \& Montmarquette, 2004)said that job satisfaction is a picture of the feelings of workers based on work experience.

As for the indicators of work dissatisfaction(Herzberg, 2003), consists of several indicators, namely: (1) Salary, (2) Institutional and administrative policies, (3) Quality of interpersonal relationships between colleagues; with superiors; and with subordinates, (4) Supervision techniques, (5) Job security and status, (6) Additional benefits, (7) Working conditions. Satisfaction includes: (1) Achievement, (2) Recognition, (3) Work itself, (4) Responsibility, (5) Progress, (6) Possibility of growth.

\section{Organizational Justice}

Organizational justice explains an individual's perception of the treatment he receives from an organization and his behavioral reaction to that perception, organizational justice can also be described as an equality in the workplace(Omar, Amiraa, \& Halim, 2011). The framework of an organization is based on fairness and ethical behavior within the organization. Organizational justice is expressed as a personal feeling of fair pay and benefits(Farahbod, Salimi, \& Dorostkar, 2013). Organizational justice leads to managers' decisions, perceived equality, effects of fairness, the relationship between individuals and the work environment, and explains individual perceptions about fairness in the workplace. (Greenberg \& Baron, 2007)stated that organizational justice is as a person's or individual's perception of justice in the decision-making process and the distribution of results that have been received by that individual. Employees see their organization as fair when they believe that the results they receive and how they receive these results are fair. An important component of organizational justice is an individual's perception of justice. In another sense, justice is subjective, and lies with the individual's perception(Sekarwangi, 2014).

According to(Li \& Cropanzano, 2009)justice measurement is divided into 3 dimensions. These are: (a) Distributive: (1) Justice, (2) Needs, (3) Equations, (b) Prosuderal: (1) Consistent, (2) Lack of bias, (3) Accuracy, (4) Consideration of employee representatives , (5) Corrections, (6) Ethics, (c) Interactional: (1) Interpersonal Justice, (2) Information Justice.

\section{Job Insecurity}

(Greenhalgh \& Rosenblatt, 1984)described job insecurity as an inability to maintain the desired continuity in threatened work conditions. While(Fadzilah \& Martono, 2016)interpretedjob insecurity as a psychological condition of a person or employee who shows irritation or feels insecure due to changing environmental conditions. Such conditions arise because of the many types of work that are temporary or work based on employment contracts. The more types of work with the duration of time that is temporary or not permanent, resulting in more and more employees who feel insecurity at work(Fadzilah \& Martono, 2016).

Indicators of job insecurity according to(Greenhalgh \& Rosenblatt, 1984)consists of: (1) 


\section{International Journal of Business Management and Economic Review}

Vol. 3, No. 04; 2020

ISSN: 2581-4664

Environmental Conditions, (2) Individual Characteristics and Position of Workers, (3) Personality Characteristics of Workers.

\section{Emotional Intelligence}

(Goleman, 2018)revealed that emotional intelligence is an ability to monitor and also control one's own feelings and those of others, and to use those feelings to guide thoughts and actions. So, emotional intelligence acts as a major capital for self-control so that it can produce good performance(Patton, 1997). (Riggio, 2017)stated that good performance can bring about job satisfaction. So, if an employee has good intelligence in managing emotions, when a company forces the employee into a work situation that is not in line with his expectations, then he can use his emotional intelligence to "stay in control" of the situation and maintain a sense of "satisfaction" work "at work (Segal, 2003).

Indicators of emotional intelligence according to(Goleman, 2018)consists of: (1) recognizing one's emotions, (2) managing emotions, (3) motivating yourself, (4) recognizing the emotions of others, (5) building relationships.

\section{Research paradigm}

Based on the discussion of the problem and research literature, the researcher formulates the paradigm and research hypothesis as follows.

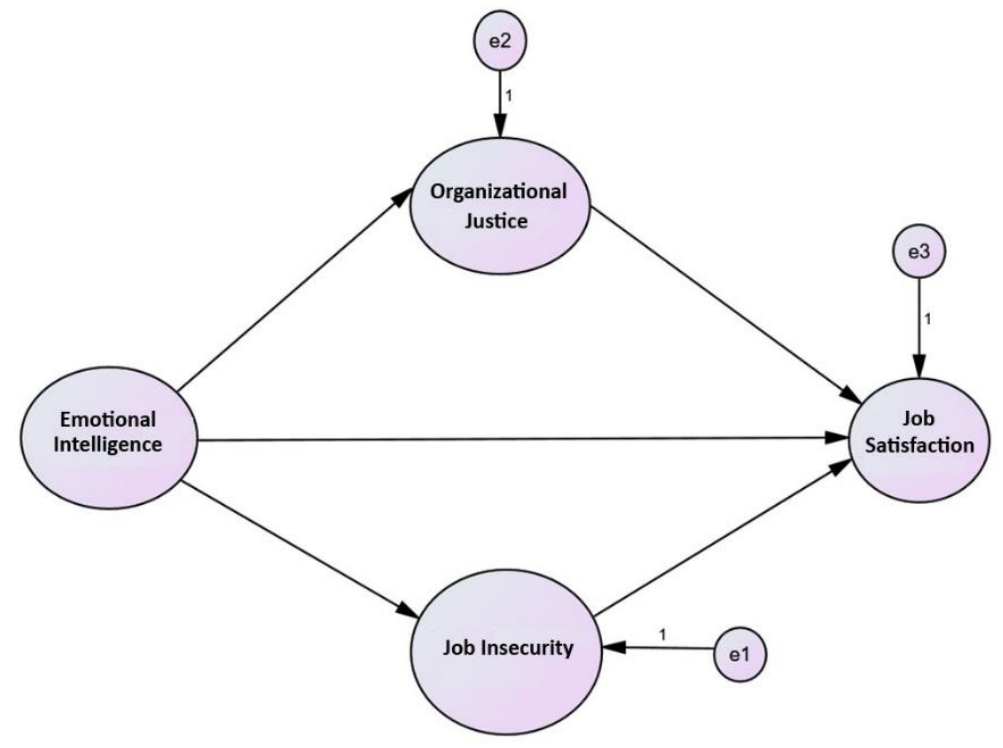

Figure 1. Research Model

H1: Emotional intelligence influences organizational justice

$\mathrm{H} 2$ : Emotional intelligence influences job insecurity

H3: Emotional intelligence influences employee job satisfaction

H4: Organizational justice influences employee job satisfaction

H5: Job insecurity influences employee job satisfaction

H6: Organizational justice mediates the influence of emotional intelligence on employee job 


\section{International Journal of Business Management and Economic Review}

Vol. 3, No. 04; 2020

ISSN: 2581-4664

satisfaction

H7: Job insecurity mediates the influence of emotional intelligence on employee job satisfaction

\section{RESEARCH METHOD}

To obtain accurate and relevant data and research needed to complete this research, a series of direct studies were conducted at the Aceh Province Government Secretariat environment. While the variables of this study are the emotional intelligence, job satisfaction, organizational justice and employee job insecurity.

The population in this study were leaders and employees, amounting to 595 within the Aceh Province Government Secretariat. The method used in this research was the probability sampling method. The type of probabilty sampling chosen was proportionate stratified random sampling, as a systematic random sampling of subjects by dividing the population by n portions and taking a sample in each section starting from the first part at random. The number of Sample in this study was determined using the Slovin formula so that the sample size was 161 respondents. The research model was analyzed using Structural Equation Modeling (SEM) through the use of the Amos application.

The SEM equation model is a combination of statistical techniques that can test a series of relatively complex relationships simultaneously(Hair, Hult, Ringle, \& Sarstedt, 2016).SEM is able to enter latent variables into the analysis. Before testing the hypothesis, confirmatory factor analysis (CFA). CFA in SEM needs to be done to ensure that the indicators are fit(Silva \& Alwi, 2008). To test mediation variables, this study uses the Sobel test.

In this study, researchers construct constructs for each variable studied based on previous theories, where the constructs are tangible indicators, namely:

a. Job Satisfaction with measurement indicators (1) Salary, (2) Institutional and administrative policies, (3) Quality of interpersonal relationships among colleagues; with superiors; and with subordinates, (4) Supervision techniques, (5) Job security and status, (6) Additional benefits, (7) Working conditions. Satisfaction includes: (1) Achievement, (2) Recognition, (3) Work itself, (4) Responsibility, (5) Progress, (6) Possibility of development.

b. Organizational Justice with measurement indicators (a) Distributive: (1) Fairness, (2) Needs, (3) Equation, (b) Prosuderal: (1) Consistent, (2) Lack of bias, (3) Accuracy, (4) Consideration employee representatives, (5) Corrections, (6) Ethics, (c) Interactional: (1) Interpersonal Justice, (2) Information Justice.

c. Job insecurity with measurement indicators (1) Environmental Conditions, (2) Individual Characteristics and Position of Workers, (3) Personal Characteristics of Workers.

d. Emotional intelligence with measurement indicators (1) Recognizing emotions, (2) Managing emotions, (3) Motivating yourself, (4) Recognizing the emotions of others, (5) Establishing relationships.

\section{RESULTS AND DISCUSSION}

Structural model analysis that explains the test of influence between variables is presented in the following path diagram: 


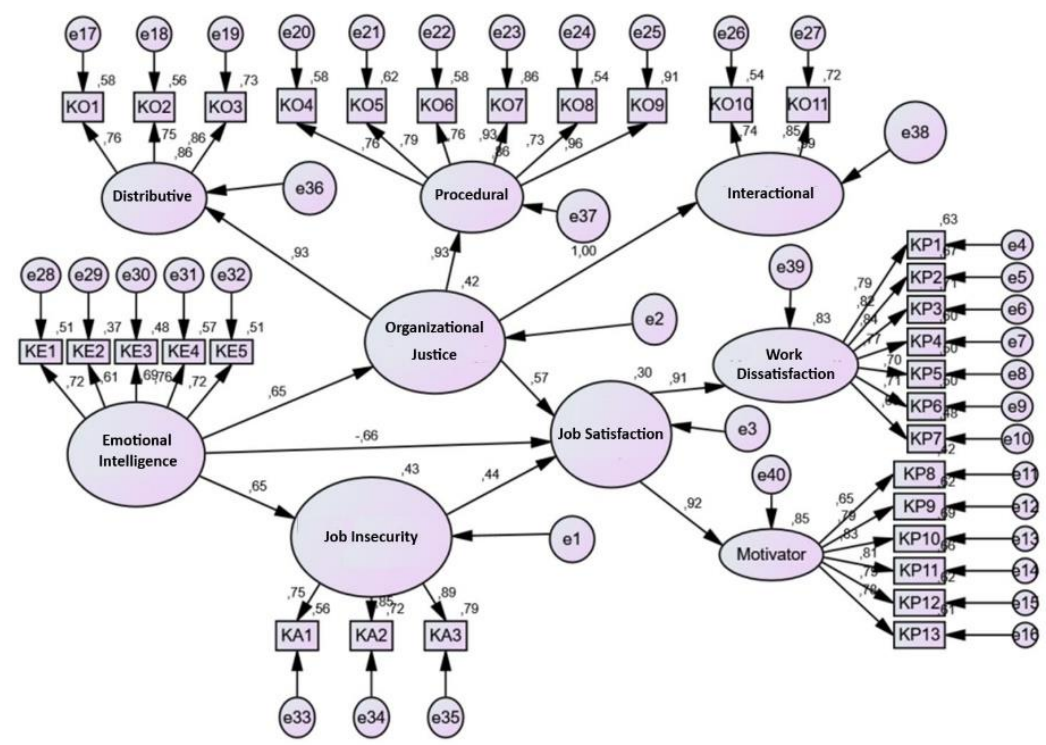

Figure 2. Hypothesis Test Result

\section{Direct Effect}

The results of testing the full model for testing hypotheses after going through the fulfillment of SEM assumptions, more clearly especially for the direct effect are in the following table:

Table 1. Hypothesis Testing Results

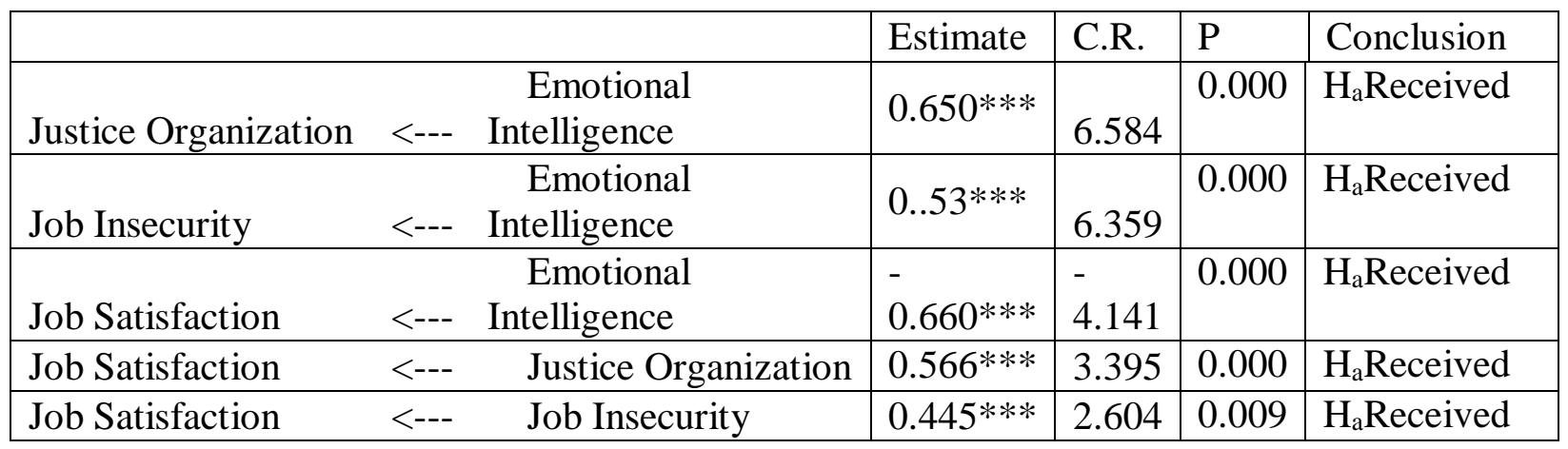

Source: Questionnaire / Primary Data, 2020 (processed)

1. Correlation of emotional intelligence towards organizational justice within the Aceh Province Government Secretariat

The influence of emotional intelligence towards organizational justice within the Aceh Province Government Secretariat obtained a significance value of 0.000 , with a correlation 


\section{International Journal of Business Management and Economic Review}

Vol. 3, No. 04; 2020

ISSN: 2581-4664

value of 0.650 . This concludes that emotional intelligence has a strong influence on organizational justice. So by implication, the better the emotional intelligence will have a direct and strong influence on improving organizational justice.

2. Correlation of emotional intelligence towardsjob insecurity in the Aceh Province Government Secretariat

The influence of emotional intelligence towardsjob insecurity in the Aceh Province Government Secretariat obtained a significance value of 0.000 , with a correlation value of 0.653 . This reveals that emotional intelligence has a strong influence on job insecurity. So by implication, the higher emotional intelligence can provide a direct and strong influence on increasing job insecurity.

3. Correlation of emotional intelligence towards job satisfaction in the Aceh Province Government Secretariat

The influence of emotional intelligence towards job satisfaction within the Aceh Province Government Secretariat obtained a significance value of 0.000 , with a correlation value of 0,660 . So it can be said that emotional intelligence has a strong influence on job satisfaction. So by implication, the better emotional intelligence will have a direct influence and can change employee job satisfaction.

4. Correlation of organizational justice towards job satisfaction in the Aceh Province Government Secretariat

The effect of organizational justice towards job satisfaction within the Aceh Province Government Secretariat obtained a significance value of 0.000 , with a correlation value of 0.566 . This defines that organizational justice has a strong influence on job satisfaction. So by implication, the better organizational justice will have a direct and strong influence on increasing employee satisfaction.

5. Correlation of job insecurity towards job satisfaction in the Aceh Province Government Secretariat

The effect of job insecurity towards job satisfaction within the Aceh Province Government Secretariat obtained a significance value of 0.000 , with a correlation value of 0.445 . This indicates that job insecurity has a strong influence on job satisfaction. So by implication, the better job insecurity will have a direct and strong influence on increasing employee job satisfaction.

\section{Indirect Effect}

In the following discussion, we will see the direct and indirect effects of each variable, but first the magnitude of the coefficients must be seen, based on the results of SEM calculations as shown in Table 2. 
Vol. 3, No. 04; 2020

ISSN: 2581-4664

Table 2. Direct Effects and Indirect Effects

\begin{tabular}{|c|c|c|c|c|c|c|c|c|}
\hline & $\begin{array}{l}\text { Total } \\
\text { Effec } \\
t\end{array}$ & $\begin{array}{l}\text { Direc } \\
t \\
\text { Effec } \\
t\end{array}$ & S.E & $\begin{array}{l}\text { Ind. } \\
\text { Effec } \\
\text { t }\end{array}$ & $\begin{array}{l}\text { Sobel } \\
\text { Test }\end{array}$ & $\begin{array}{l}\text { S.E } \\
\text { (Ind) }\end{array}$ & C.R & $P$ \\
\hline $\begin{array}{l}\text { Justice Organization } \\
\leftarrow \text { Emotional } \\
\text { Intelligence }\end{array}$ & 0.650 & 0.650 & $\begin{array}{l}0.13 \\
2\end{array}$ & & & & 6.584 & 0.000 \\
\hline $\begin{array}{l}\text { Job Insecurity } \\
\leftarrow \text { Emotional } \\
\text { Intelligence }\end{array}$ & 0.653 & 0.653 & $\begin{array}{l}0.16 \\
1\end{array}$ & & & & 6.359 & 0.000 \\
\hline $\begin{array}{l}\text { Job Satisfaction } \\
\leftarrow \text { Emotional } \\
\text { Intelligence }\end{array}$ & $\overline{-} 0.002$ & $\overline{-}-660$ & $\begin{array}{l}0.18 \\
5\end{array}$ & & & & $-\overline{4}$ & 0.000 \\
\hline $\begin{array}{l}\text { Job Satisfaction } \\
\leftarrow \text { Organizational } \\
\text { Justice }\end{array}$ & 0.566 & 0.566 & $\begin{array}{l}0.14 \\
4\end{array}$ & & & & 3.395 & 0.000 \\
\hline $\begin{array}{l}\text { Job Satisfaction } \\
\leftarrow \text { Job Insecurity }\end{array}$ & 0.445 & 0.445 & $\begin{array}{l}0.12 \\
7\end{array}$ & & & & 2.604 & 0.009 \\
\hline $\begin{array}{l}\text { Job Satisfaction } \\
\leftarrow \text { Organizational } \\
\text { Justice } \\
\leftarrow \text { Emotional } \\
\text { Intelligence }\end{array}$ & & & & 0.658 & 3.071 & 0.119 & & 0.002 \\
\hline $\begin{array}{l}\text { Job Satisfaction } \\
\leftarrow \text { Job Insecurity } \\
\leftarrow \text { Emotional } \\
\text { Intelligence }\end{array}$ & & & & 0.658 & 2.651 & 0.109 & & 0.008 \\
\hline
\end{tabular}

To answer the mediation hypothesis, then the data will be analyzed using the bootstraping method using AMOS to see the value of S.E. and p-value on the effect of total effect, direct effect and indirect effect. To find the value of the sobel test, a calculator software developed by (Preacher \& Leonardelli, 2010) was used, based on table 2. it explaines the mediation hypothesis testing as for the hypothesis 6 and 7.

6. The indirect effect of emotional intelligence on job satisfaction through organizational justice in the Aceh Regional Secretariat

After testing the indirect effect in accordance with the method described by (Baron \& Kenny, 1986)

the results show the indirect effect of emotional intelligence on job satisfaction through organizational justice, namely $0.658(\mathrm{p}=0.002)$ of the total effects $(\mathrm{c}) 0.650(\mathrm{p}=0.000)$, 


\section{International Journal of Business Management and Economic Review}

Vol. 3, No. 04; 2020

ISSN: 2581-4664

the direct effect $\left(c^{\prime}\right)$ is $0.650(p=0.000)$ with a sobel value of 3.071> 1.960. So it describes thehypothesis 6 has proven that emotional intelligence influences job satisfaction through organizational justice. The role of organizational justice is proven as a partial mediator.

7. The indirect effect of emotional intelligence on job satisfaction through job insecurity in the Aceh Regional Secretariat

After testing the indirect effect in accordance with the method described by (Baron \& Kenny, 1986) the results show the indirect value of emotional intelligence on job satisfaction through job insecurity that is $0,658(\mathrm{p}=0.002)$ of the total effect (c) $0.653(\mathrm{p}=0.000)$, the direct effect (c ') of $0.653(\mathrm{p}=0.000)$ with a sobel value of 2.651> 1,960 . So it describes thehypothesis 6 has proven that emotional intelligence influences job satisfaction through job insecurity. The role of job insecurity is proven as a partial mediator.

\section{CONCLUSION}

The result proves that emotional intelligence affects employee organizational justice, emotional intelligence affects job insecurity, emotional intelligence affects employee job satisfaction, organizational justice affects employee job satisfaction, job insecurity affects employee job satisfaction, organizational justice mediates the influence of emotional intelligence on job satisfaction, job insecurity mediates the influence of emotional intelligence on job satisfaction. These findings contribute academically, especially in the renewal of the theory of causality and can be a reference for practical leaders, especially those in the Aceh Province Government Secretariat.

Some practical concepts as managerial implications for practitioners on research object can be mapped. Agency policies are needed that lead to increased emotional intelligence of employees, so that emotional control of employees at work can be increased again. Agencies can hold activities such as seminars, training or other activities related to personal development and emotional intelligence, can be carried out inside or outside the room. Leaders need to make an estimate of how much the dominant factor causes emotional intelligence where the indicators are Recognizing self-emotion (Self awareness), Managing emotions (Self Management), Motivating yourself (Motivation), Recognizing the emotions of others and Building relationships (Relationship management) so they can work professionally and keep them working. Leaders must be able to make activities that make co-workers happy.

Echelonering officials must pay attention and take a position that can improve organizational fairness and make employees feel safe to produce optimal performance. Echelonering officials can always improve employee job satisfaction by rewarding outstanding employees, providing opportunities for subordinates to be promoted as career guarantees in the future, improving the quality of the work environment and improving relations between employees so as to create employee harmony in their essence.

In the variable of emotional intelligence the most dominant indicator is employees looking for activities that make employees happy when employees feel bored with the work that is pretty much carried and face the attitudes of colleagues, suggestions for overcoming it are employees can work while listening to music, or while enjoying snacks, or also scheduled a weekend vacation to a tourist place once a month or two months with colleagues and family. In the organizational justice variable, the most dominant indicator is the procedure of working in 


\section{International Journal of Business Management and Economic Review}

Vol. 3, No. 04; 2020

ISSN: 2581-4664

the institution where the employee is in accordance with the assigned function, therefore the employee leader must recognize the weaknesses and shortcomings of his employees as the basis for the division of tasks to his employees.

In the variable work insecurity, the most dominant indicator is that employees feel uneasy when work will be lost because if they do not work accordingly there is little opportunity for promotion. In this condition the reward and punishment system can be improved, allowing employees to work better and more passionately. In the variable job satisfaction has a dimension of job dissatisfaction where the highest indicator lies in the salary received in accordance with the work performed, because it is in accordance with the existing rank. But if they serve as structural get a post allowance.

\section{REFERENCES}

Baron, R. M., \& Kenny, D. A. (1986). The Moderator-Mediator Variable Distinction in Social Psychological Research: Conceptual, Strategic, and Statistical Considerations. Journal of Personality and Social Psychology, 51(6), 1173-1182.

Colquitt, J. A. (2001). On the Dimensionality of Organizational Justice:A Construct Validation of a Measure. Journal of Applied Psychology, 86(3), 386-400. https://doi.org/10.1037//0021-9010.86.3.386

Fadzilah, \& Martono, S. (2016). Pengaruh Ketidakamanan Kerja, Komitmen Organisasional Dan Kepercayaan Organisasional Pada Keinginan Berpindah. Management Analysis Journal, 5(3), 167-177.

Farahbod, F., Salimi, S. B., \& Dorostkar, K. R. (2013). Impact of Organizational Communication in Job Satisfaction and Organizational Commitment (Case Study Maskan Bank Guilan). Interdisciplinary Journal Of Contemporary Research In Business, 5(4), 419-430.

Goleman, D. (2018). Emotional Intelligence, Buku Menggemparkan yang Mendefinisikan Ulang Apa Arti Cerdas (25th ed.; T. Hermaya, Ed.). Jakarta: Gramedia Pustaka Utama.

Greenberg, J., \& Baron, R. A. (2007). Behavior In Organizations (9th ed.). United States: Prentice Hall.

Greenhalgh, L., \& Rosenblatt, Z. (1984). Job Insecurity: Toward Conceptual Clarity. Academy of Management Review, 9(3), 438-448.

Hair, J. F., Hult, G. T. M., Ringle, C., \& Sarstedt, M. (2016). A Primer on Partial Least Squares Structural Equation Modeling (PLS-SEM) (2nd ed.). Thousand Oaks: Sage Publications, Inc.

Herzberg, F. (2003). One More Time: How Do You Motivate Employees? Harvard Business Review, 81(1).

Lévy-Garboua, L., \& Montmarquette, C. (2004). Reported job satisfaction: what does it mean? The Journal of Socio-Economics, 33(2), 135-151. https://doi.org/https://doi.org/10.1016/j.socec.2003.12.017

Li, A., \& Cropanzano, R. (2009). Fairness at the Group Level: Justice Climate and Intraunit Justice Climate. Journal of Management, 35(3), 564-599. https://doi.org/10.1177/0149206308330557

Luthans, F. (2006). Perilaku Organisasi (Edisi 10).(v. A. Yuwono, S. Purwanti, TA P, \& W. Rosari, Trans.) Yogyakarta: ANDI.

Muttaqin, N. I., Djumadi, \& Noor, M. (2013). Pengaruh Motivasi Kerja Terhadap Pelayanan 


\section{International Journal of Business Management and Economic Review}

Vol. 3, No. 04; 2020

ISSN: 2581-4664

Publik Di Kantor Camat Tenggarong Kabupaten Kutai Kartanegara. EJournal Administrative Reform, 1(1), 246-256.

Omar, F., Amiraa, A. M., \& Halim, F. W. (2011). The relationships between organizational justice, organizational citizenship behavior and job satisfaction. Pertanika Journal of Social Science and Humanities, 19(S), 115-121.

Patton, P. (1997). Emotional intelligence di tempat kerja (P. Patton, D. Zaini, \& J. Tahitoe, Eds.). Jakarta: Pustaka Delapratasa.

Preacher, K. J., \& Leonardelli, G. J. (2010). Calculation for the Sobel test: An interactive calculation tool for mediation tests. Retrieved February 9, 2020, from quantpsy.org website: http://quantpsy.org/sobel/sobel.htm

Riggio, R. E. (2017). Introduction to Industrial/Organizational Psychology. New York: Routledge.

Rivai, V., \& Mulyadi, D. (2003). Kepemimpinan dan perilaku organisasi. Jakarta: Raja Grafindo Persada.

Robbins, S. P., \& Judge, T. A. (2014). Buku Perilaku Organisasi Buku 2 (Edisi ke-1; alih bahasa D. Angelica, Ed.). Salemba Empat.

Segal, J. (2003). Melejitkan Kepekaan Emosional. Penerjemah Ary Nilandari. In Bandung: Kaifa. Bandung: Kaifa.

Sekarwangi, E. (2014). Pengaruh Stress Kerja da Keadilan Organisasi terhadap Employee engagement. Universitas Gadjah Mada.

Silva, R. V. Da, \& Alwi, S. F. S. (2008). Online brand attributes and online corporate brand images. European Journal of Marketing, 42(9), 1039-1058. https://doi.org/https://doi.org/10.1108/03090560810891136 